\title{
Hubungan Kadar Hb Ibu Inpartu Terhadap Kejadian BBLR di RSUD Kabupeten Nganjuk Periode Bulan Maret-April Tahun 2013
}

\author{
(Relation of the Hemoglobin Rate Inpartu Mother Against Low Birth Weight in Nganjuk \\ District The Period Month Of March-April 2013)
}

\author{
Eny Sendra, Clairine Maretha Martin Putra \\ Poltekkes Kemenkes Malang \\ Prodi Kebidanan Kediri Jl.KH.Wakhid Hasyim 64 B Kediri
}

\begin{abstract}
The report of the Health Office District/City Health on 2012, It is known that the number of LBW baby in East Java is 3,32\% .And the number of LBW birth in Kediri is $2,24 \%$. There are lower than the rate of LBW births in Nganjuk. The LBW births in Nganjuk is $3.39 \%$. There found 260 cases in 2012 and 272 cases in 2013. LBW is one of the biggest causes of neonatal death. LBW can be caused by many factors, There are maternal factors, fetal factors, placental factors and eviromental. The purpose of this study is for knowing relation hemoglobin rate inpartu mother against the incidence of low birth weight. The population of this study used 31 respondent who mother give birth to LBW baby by simple Random sampling techniques, It get 29 sample of mother who give birth to LBW baby. These variables of study are measured by documentation guideline, the results of the status medical record patients. This study method use Cross Sectional design by independent variable of hemoglobin rate inpartu mother and dependent variable of the incidence of LBW by using the Spearman Rank Test. The result from Spearman Rank analysis there was not relation $\mathrm{Hb}$ rate inpartu mother against incidence of low birth weight ( calculate $\rho=-0,031$ and $\rho$ table $5 \%=1,699$ so calculate $\rho<\rho$ table) so it can be concluded that Ho is accepted at significance level 0.05. It can conclude so there is no relation $\mathrm{Hb}$ rate inpartu mother against incident of low birth weight.
\end{abstract}

Keywords: low birth weight, maternal Hb inpartu

\section{Pendahuluan}

Kehamilan adalah masa di mana seorang wanita memiliki janin yang sedang tumbuh di dalam tubuhnya. Dan saat itu pula, kebutuhan makanan bergizi perlu ditingkatkan. Karena pada saat itu, ibu hamil bukan hanya makan untuk dirinya saja, namun juga untuk janin yang ada di perutnya. Selama kehamilan, jumlah makanan menjadi penting, yang paling penting adalah makan-makanan bergizi (Sinsin, 2008).

Untuk mencapai sasaran Millenium Development Goals (MDGs), yaitu Angka Kematian Bayi (AKB) menjadi 23 per $1.000 \mathrm{KH}$ pada tahun 2015 , perlu upaya percepatan yang lebih besar dan kerja keras karena kondisi saat ini, AKB 34 per $1.000 \mathrm{KH}$. Salah satu penyebab AKB disebabkan dari berat bayi lahir tidak normal (MDGS, 2010).

Diketahui bahwa jumlah bayi dengan Berat Badan Lahir Rendah (BBLR) di Jawa Timur mencapai $3,32 \%$ yang diperoleh dari persentase 19.712 bayi dari 594.461 bayi baru lahir yang ditimbang. Untuk jumlah kelahiran BBLR di Kabupaten Kediri yaitu 2,24\%. Angka kelahiran tersebut lebih rendah dibandingkan dengan angka kelahiran BBLR di Kabupaten Nganjuk yaitu 3,39 $\%$. Berdasarkan Laporan Tribulan (LB3) tahun 2012 Kesehatan Ibu dan Anak (Seksi Kesehatan Keluarga Dinas Kesehatan Provinsi Jawa Timur), kematian neonatal yang disebabkan oleh BBLR mencapai $38,03 \%$ dan ini merupakan angka tertinggi dibandingkan 
penyebab lainnya. BBLR merupakan salah satu penyebab kematian neonatal.

Dari Studi Pendahuluan yang dilakukan di RSUD Nganjuk ditemukan bahwa jumlah bayi yang lahir dengan berat badan lahir rendah pada tahun 2012 ada 260 kasus dari 2484 jumlah persalinan. Pada tahun 2013 di temukan 272 kasus dari 1068 jumlah persalinan.

Menurut Fraser dan Cooper (2011 : 763) mengatakan bahwa salah satu penyebab hambatan pertumbuhan intrauterine adalah kadar hemoglobin yang kurang dalam darah. Sehinga kadar hemoglobin yang kurang dalam darah juga dapat menghambat pertumbuhan janin dalam kandungan.

Pengukuran kadar $\mathrm{Hb}$ untuk mengetahui kondisi ibu apakah ibu menderita anemia gizi besi. (Fraser dan Cooper, 2011 : ).

Dengan mengukur Kadar $\mathrm{Hb}$ dapat diketahui anemia gizi atau tidaknya seseorang. Dengan mengambil sedikit darah di ujung jari, kadar $\mathrm{Hb}$ dapat dengan mudah diketahui. Pada kehamilan trimester tiga hingga menjelang persalinan, wanita hamil seringkali terkena anemia, karena pada masa ini janin menimbun cadangan zat besi untuk dirinya sendiri sebagai persediaan bulan pertama sesudah lahir (Sinsin,2008).

Menurut WHO kematian ibu yang disebabkan oleh defisiensi besi dan perdarahan akut mencapai $40 \%$. Kadar $\mathrm{Hb}$ yang kurang pada wanita hamil dan berlangsung hingga kepersalinan merupakan masalah kesehatan yang dialami oleh seluruh wanita di dunia terumata di negara berkembang (Indonesia). Laporan dari WHO mengatakan $35-75 \%$ wanita hamil mengalami defisiensi serta meningkat seiring dengan bertambahnya usia kehamilan. Kadar $\mathrm{Hb}$ yang kurang dalam kehamilan meningkatkan resiko kematian maternal, angka prematuritas, peningkatkan angka kematian perinatal, dan kelahiran BBLR. Banyak faktor yang menyebabkan timbulnya anemia antara lain dikarenakan kurang gizi dan kurangnya asupan zat besi dan protein dari makanan (Rukiyah, Yeyeh dan Yulianti,2010).

Low first-trimester hemoglobin and low birth weight, preterm birth and small for gestational age newborn. : Ren A, Wang J, Ye R.W, dkk (2007) bahwa wanita dengan $\mathrm{Hb}$ 80-99 $\mathrm{g} / \mathrm{L}$ memiliki pengaruh signifikan yang tinggi terhadap kejadian BBLR, kehamilan cukup bulan dan kecil masa kehamilan dari pada wanita yang memiliki $\mathrm{Hb}$ 100-119 g/L. dan Tidak ada peningkatan risiko tercatat untuk wanita dengan $\mathrm{Hb} \geq 120 \mathrm{~g} / \mathrm{L}$.

Preconception Hemoglobin and Ferritin Concentrations Are Associated with Pregnancy Outcome in a Prospective Cohort of Chinese Women. : Ronnenberg Alayne G, Wood Richard J, Wang Xiaobin, dkk (2004) bahwa anemia Prenatal dan kekurangan zat besi memiliki hubungan yang merugikan dengan hasil kelahiran, peneliti meneliti hubungan antara anemia prakonsepsi , kekurangan zat besi , dan hasil akhir kehamilan pada wanita yang sehat pada 405 perempuan Cina yang diteliti ( waktu median dari koleksi sampel untuk kehamilan akhir 316 ). Keduanya ringan $(95 \leq \mathrm{Hb}<120) \mathrm{g} /$ $\mathrm{L}$ dan moderat $\mathrm{Hb}(<95 \mathrm{~g} / \mathrm{L})$ anemia secara signifikan terkait dengan berat lahir rendah ( 139 dan $192 \mathrm{~g}$, masing-masing); besi - anemia defisiensi sendiri $(\mathrm{Hb}<120$ $\mathrm{g}$, feritin < 12 mikrogram / L , ada kekurangan vitamin B ) dikaitkan dengan 242 g penurunan berat lahir. Keduanya rendah ( $<12$ mikro gram / L ) dan tinggi ( $\geq 60$ mikrogram / L ). Prasangka , khususnya anemia defisiensi besi , dikaitkan dengan mengurangi pertumbuhan bayi dan meningkatkan risiko hasil kehamilan yang merugikan pada wanita Cina.

Penelitian yang dilakukan oleh Rahayu W. (2005), menunjukkan bahwa sebanyak 40 ibu hamil dan 40 janin diperoleh bayi dengan Berat Bayi Lahir Normal (BBLN) yang dilahirkan dari ibu hamil yang sukses dalam pencapaian 
kadar hemoglobin harapan sebesar 100\% dan yang gagal dalam pencapaian kadar hemoglobin harapan sebesar $61,5 \%$ diperoleh bayi dengan Berat Bayi Lahir Rendah (BBLR) yang dilahirkan dari ibu hamil yang sukses dalam pencapaian kadar hemoglobin harapan sebesar $0 \%$ dan yang gagal dalam pencapaia kadar hemoglobin harapan sebesar 38,5\%.

Berdasarkan studi pendahuluan di RSUD Nganjuk pada bulan Januari 2013, didapatkan 14 ibu inpartu yang di tes kadar Hemoglobin, dimana jumlah ibu inpartu yang melahirkan bayi BBLR dengan kadar hemoglobin di bawah normal ada 7 orang dan sisanya ( 7 orang ) dengan kadar hemoglobin normal melahirkan bayi dengan BBLR. Pada bulan Februari didapatkan 18 ibu inpartu yang di tes kadar hemoglobin, dimana jumlah ibu inpartu yang melahirkan bayi BBLR dengan kadar hemoglobin di bawah normal ada 6 orang dan 12 orang lainnya melahirkan bayi BBLR dengan kadar hemoglobin normal.

Ketika ibu mulai hamil maka perlu ditingkatkan pelayanan / asuhan antenatal untuk memeriksakan sedini mungkin, diperlukan pula monitoring untuk mendukung kesehatan ibu hamil serta mendeteksi kehamilan ibu hamil agar berjalan secara normal tanpa ada komplikasi hingga menjelang persalinan (Prawirohardjo, Sarwono, 2010).

Kadar hemoglobin yang kurang dalam darah juga dapat menghambat pertumbuhan janin dalam kandungan, kadar hemoglobin yang kurang ketika menjelang persalinan menunjukkan bahwa selama kehamilan kadar hemoglobin dalam darah ibu kemungkinan juga akan berkurang, hal ini merupakan salah satu yang bisa menyebabkan kelahiran bayi dengan Berat Badan Lahir Rendah.

\section{Metode Penelitian.}

Desain penelitian ini menggunakan metode survei analitik dengan rancangan Cross Sectional. Penelitian Cross
Sectional. Dalam penelitian ini, variabel terikat (berat badan lahir rendah) dan variabel bebas (kadar $\mathrm{Hb}$ ) akan diamati dalam waktu yang sama dan dinilai hanya satu kali tanpa adanya tindak lanjut.

Populasi dalam penelitian ini adalah 31 ibu yang melahirkan bayi dengan berat badan lahir rendah di RSUD Nganjuk Periode Maret-April Tahun 2013.

Sampel dari penelitian ini sebanyak 29 ibu yang melahirkan BBLR di RSUD Nganjuk dengan teknik pengambilan sampel dengan menggunakan Simple Random Sampling.Analisis data univariate (analisis deskriptif) untuk menjelaskan atau mendeskripsikan karakteristik setiap variabel penelitian.

Peneliti melakukan uji statistik dengan Spearman Rank untuk menganalisis data antara Kadar $\mathrm{Hb} \mathrm{Ibu}$ Inpartu dengan Kejadian BBLR adalah Spearman Rank dengan taraf signifikansi 0,05 .

\section{Hasil Penelitian \\ Data Umum}

\section{Usia Ibu Inpartu}

Usia Ibu Inpartu Yang Melahirkan bayi BBLR di RSUD Nganjuk dapat dilihat pada diagram batang sebagai berikut :

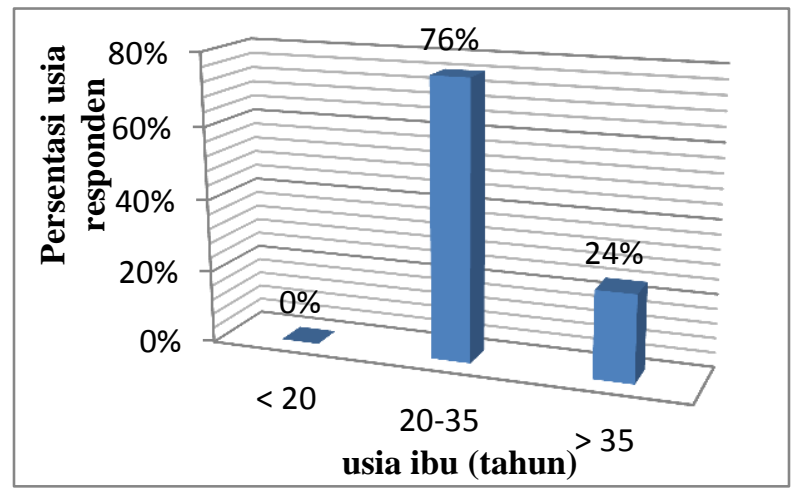

Berdasarkan diagram diatas diketahui bahwa dari 29 ibu inpartu, sebagian besar ibu inpartu yaitu $76 \%$ berusia 20-35 tahun. 


\section{Graviditas}

Graviditas Ibu Inpartu Yang Melahirkan bayi BBLR di RSUD Nganjuk dapat dilihat pada diagram batang sebagai berikut :

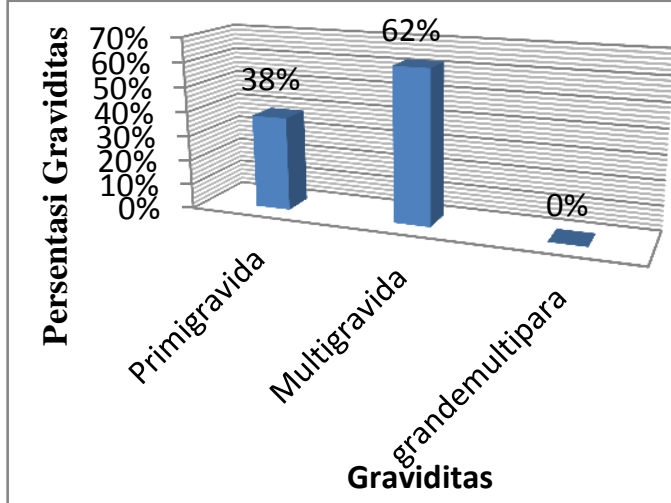

Berdasarkan diagram diatas diketahui bahwa dari 29 ibu inpartu, sebagian besar ibu inpartu yaitu $62 \%$ adalah multigravida.

\section{Usia Kehamilan}

Usia Kehamilan Ibu Inpartu Yang Melahirkan bayi BBLRdi RSUD Nganjuk dapat dilihat pada diagram batang sebagai berikut :

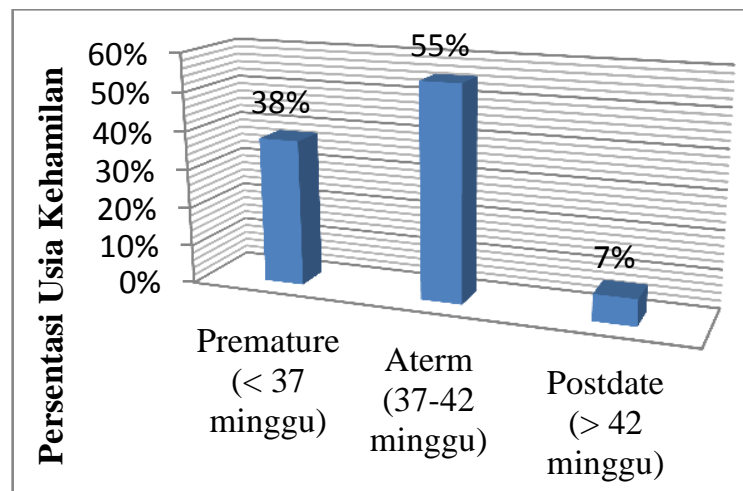

Usia Kehamilan

Berdasarkan diagram diatas diketahui bahwa dari 29 ibu inpartu, lebih dari setengah ibu inpartu yaitu $55 \%$ memiliki usia kehamilan aterm.

\section{Penyulit}

Penyulit Ibu Inpartu Yang Melahirkan bayi BBLR di RSUD Nganjuk dapat dilihat pada diagram batang sebagai berikut :

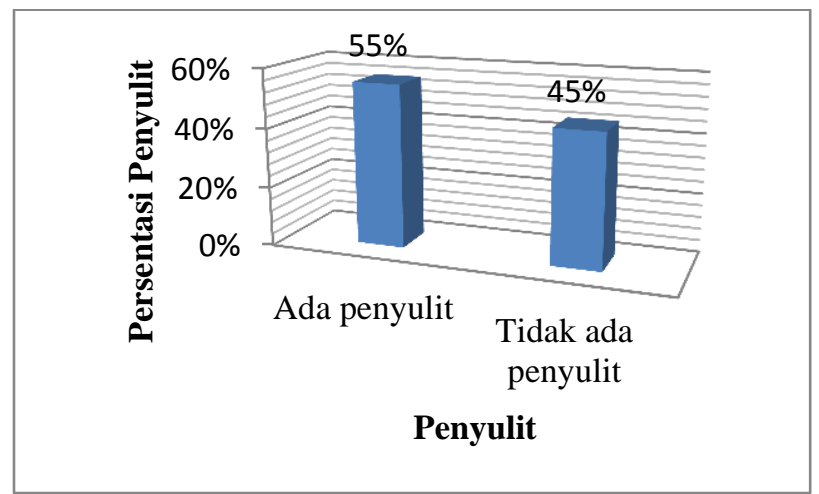

Berdasarkan diagram diatas diketahui bahwa dari 29 ibu inpartu, lebih dari setengah ibu inpartu yaitu $55 \%$ ada penyulit. Penyulit tersebut ialah yaitu 4 responden dengan PEB, 7 responden dengan PER, 2 responden dengan plasenta previa, 1 responden dengan KPD, 1 responden dengan KPD+PER, 1 responden dengan PER+Plasenta Previa.

\section{Data Khusus}

\section{Kadar Hb Ibu Inpartu}

Kadar $\mathrm{Hb}$ Ibu Inpartu Yang Melahirkan bayi BBLR di RSUD Nganjuk dapat dilihat pada diagram batang sebagai berikut :

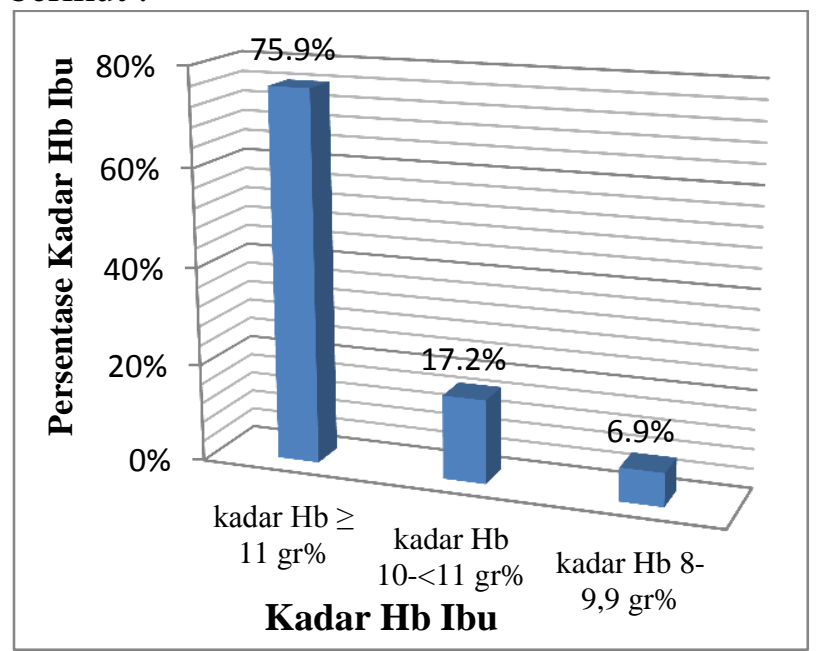

Berdasarkan diagram daiatas diketahui bahwa dari 29 ibu inpartu, sebagian besar ibu inpartu yaitu $75.9 \%$ memiliki kadar $\mathrm{Hb} \geq 11 \mathrm{gr} \%$. 


\section{BBLR (Berat Badan Lahir Rendah)}

Ibu Inpartu yang melahirkan bayi BBLR di RSUD Nganjuk dapat dilihat pada diagram batang sebagai berikut :

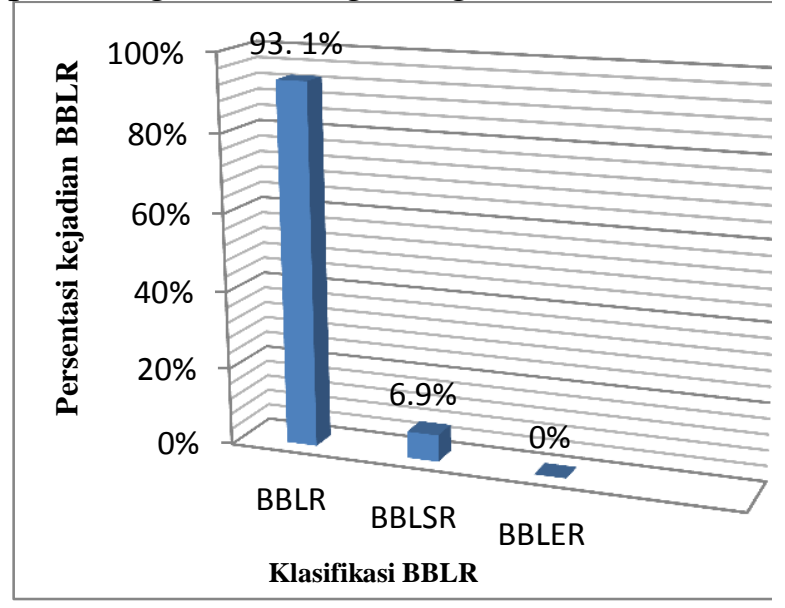

Berdasarkan diagram diatas diketahui bahwa dari 29 ibu inpartu yang melahirkan bayi dengan BBLR, mayoritas melahirkan bayi BBLR yaitu 93,1 \% dengan klasifikasi bayi BBLR yaitu berat dibawah 2500 gram.

\section{Hubungan Kadar Hb Ibu Inpartu Terhadap Kejadian BBLR di RSUD Kabupaten Nganjuk.}

Berikut hasil analisis data hubungan kadar Hb Ibu Inpartu Terhadap Kejadian BBLR di RSUD kabupaten Nganjuk. Maka dengan menggunakan rumus korelasi spearman maka dapat dihitung hasil koefisien korelasi Spearman Rank (Lampiran 9 dan 10hal : 58-59)

Dari hasil perhitungan didapatkan nilai $\rho$ hitung $=0,031<\rho$ tabel pada taraf signifikansi $5 \%=0,3705$, maka dapat disimpulkan Ho diterima pada derajat kemaknaan 0,05 artinya tidak ada hubungan kadar $\mathrm{Hb}$ ibu inpartu dengan kejadian berat badan lahir rendah.

\section{Pembahasan}

\section{Mengidentifikasi Kadar Hemoglobin Ibu Inpartu}

Hasil Penelitian menunjukkan dari 29 ibu inpartu sebagian besar ibu inpartu yaitu $75.9 \%$ memiliki kadar $\mathrm{Hb} \geq 11 \mathrm{gr} \%$,
17,2\% memiliki kadar $\mathrm{Hb} 10-<11 \mathrm{gr} \%$ dan 6,9\% memiliki kadar $\mathrm{Hb} 8-9,9 \mathrm{~g} \%$.

Menurut Bakta (2013) bahwa bila kadar $\mathrm{Hb} \geq 11 \mathrm{gr} \%$ maka tidak anemia, bila kadar $\mathrm{Hb} 10$ gr\% sampai< 11 gr\% disebut anemia ringan sekali, bila kadar $\mathrm{Hb}$ berkisar antara8gr \% sampai 9,9 gr \% maka terkena penyakit anemia ringan, bila kadar 6 gr sampai 7,9 gr \% maka terkena penyakitanemia sedang dan apabila memiliki kadar $\mathrm{Hb}<6$ gr\% maka mengalami penyakit anemia berat.

Dari penjelasan diatas dapat diketahui bahwa hasil penelitian yang telah dilakukan di RSUD Kabupaten Nganjuk diketahui ada $75,9 \%$ ibu yang tidak anemia dan ada $17,2 \%$ ibu tersebut terkena anemia ringan sekali, serta sisanya ada 6,9\%ibu terkena anemia ringan. Hal ini menunjukkan bahwa kadar $\mathrm{Hb}$ yang dimiliki selama hamil hingga menjelang bersalin tidak terlalu buruk karena kadar $\mathrm{Hb}$ yang dimiliki hanya menunjukkan anemia dengan batas ringan tidak sampai pada anemia berat.

Menurut Manuaba (2007), kadar Hb dapat mempengaruhi hambatan tumbuh kembang janin dalam rahim. Menurut Proverawati dan Sulistyorini (2010), faktor yang mempengaruhi BBLR yaitu faktor ibu, faktor janin, faktor plasenta dan faktor lingkungan.

Kadar $\mathrm{Hb}$ ibu inpartu termasuk dalam faktor ibu yang dapat mempengaruhi kelahiran bayi BBLR. Kurangnya kadar $\mathrm{Hb}$ biasanya disebabkan kurangnya zat besi. Zat besi banyak dijumpai pada makanan yang bergizi.Selama kehamilan hingga menjelang persalinan seorang ibu harus memiliki gizi yang cukup, karena gizi yang didapat dipergunakan untuk dirinya sendiri dan juga janinnya. Bila zat besi kurang selama kehamilan hingga persalinan, maka akan mempengaruhi pertumbuhan bayi dalam rahim.

Menurut Prasasti, S (2004) Hasil penelitiannya menunjukkan $44,0 \%$ ibu hamil menderita anemia dan 56,0\%tidak menderita anemia. Selain itu diperoleh $72,0 \%$ ibu hamil melahirkanbayi dengan 
berat bayi normal dan sisanya 28,0\% melahirkan berat bayilahir rendah.

Ibu hamil yang Hbnya rendah dapat membahayakan jiwa ibu yaitu risiko perdarahan sebelum dan pada saat persalinan, bahkan dapat menyebabkan kematian ibu. Ibu yang melahirkan bayi dengan BBLR tidak selalu memiliki kadar $\mathrm{Hb}$ yang rendah. Bila ibu hingga menjelang persalinan (inpartu) memiliki kadar hemoglobin yang rendah maka ibu tersebut memiliki resiko untuk melahiran bayi dengan BBLR, masih banyak resiko lainnya yang dapat mempengaruhi kelahiran bayi dengan BBLR yaitu faktor ibu, faktor janin, faktor plasenta dan faktor lingkungan.

\section{Mengidentifikasi Kejadian Berat Badan Lahir Rendah}

Hasil Penelitian menunjukkan dari 29 ibu inpartu yang melahirkan bayi dengan BBLR, mayoritas melahirkan bayi klasifikasi BBLR yaitu 93,1 \%, 6,9\% dengan klasifikasi bayi BBLSR dan tidak ada satupun bayi dalam klasifikasi BBLER $(0 \%)$.

Menurut Fraser dan Cooper (2011) menyatakan, bahwa bayi BBLRadalah bayi dengan berat badan dibawah $2500 \mathrm{~g}$ pada saat lahir, sedangkan BBLSR adalah bayi dengan berat badan dibawah1500g pada saat lahir.Klasifikasi berat badan lahir rendah di RSUD Kabupaten Nganjuk terdiri dari berat badan dibawah $2500 \mathrm{~g}$ dan berat badan dibawah $1500 \mathrm{~g}$.

Menurut Prawirohardjo, S (2009) bayi BBLR terdiri dari premature dan cukup bulan (dismatur).

Kelahiran Berat Badan Lahir Rendah bisa juga dikarenakan dari kelahiran premature dan mungkin juga karena cukup bulan. Bayi lahir premature yaitu bayi yang lahir dengan usia kehamilan kurang dari 37 minggu sehingga sebagian besar organ tubuhnya juga belum berfungsi dengan baik sehingga biasanya berat badannya kurang dari normal. Sedangkan bayi yang lahir dengan berat badan rendah dari usia cukup bulan yaitu bayi yang lahir dengan usia kehamilan 3742 minggu dimana bayi tersebut mengalami masalah gizi dalam rahim sehingga berat badan yang dihasilkan kurang dari normal.

Menurut Darmayanti, dkk (2010) Hasil analisis bivariabel menunjukkan bahwa umur kehamilan preterm memiliki risiko12,7 kali bayi lahir dengan BBLR dan analisisregresi ganda logistik menunjukkan umurkehamilan tetap berpengaruh terhadap risikoBBLR.

Hal ini tidak sama dengan hasil penelitian yang terjadi di RSUD Kabupaten Nganjuk dimana lebih dari setengan ibu inpartu yang melahirkan bayi BBLR memiliki usia kehamilan aterm (37-42minggu).

\section{Menganalisis Hubungan Kadar Hb Ibu Inpartu Terhadap Kejadian Berat Badan Lahir Rendah}

Berdasarkan uji statistik dengan menggunakan uji Spearman Rank dapat ditarik kesimpulan bahwa data dari penelitian ini menunjukkan tidak adanya hubungan antara kadar $\mathrm{Hb}$ ibu inpartu terhadap kejadian BBLR yang ditunjukkan dengan nilai $\rho=$ 0,031 dengan $\alpha=0,05$ dimana nilai $\rho$ hitung lebih kecil dibandingkan dengan nilai $\rho$ tabel $=0,3705$, sehingga dapat ditarik kesimpulan tidak adanya Hubungan Kadar Hb Ibu Inpartu Terhadap Kejadian BBLR di RSUD Kabupaten Nganjuk Periode Maret-April Tahun 2013.

Dari data sebelumnya dapat dilihat bahwa sebagian besar ibu inpartu 75,9\% memiliki kadar $\mathrm{Hb}$ normal dan mayoritas ibu inpartu melahirkan bayi BBLR yaitu 93,1 \% dengan klasifikasi bayi BBLR yaitu berat dibawah 2500 gram.

Pada kadar $\mathrm{Hb} \geq 11$ gr\% menunjukkan karakteristik 8 bayi yang lahir dengan berat badan 2200, 6 bayi yang lahir dengan berat badan 2400 gram, 2 bayi yang lahir dengan berat badan 2300gr ,2 bayi yang lahir dengan berat badan2100, serta masing-masing 1 bayi 
yang lahir dengan berat badan 1700 gr, 1600gr, 1500 gr, dan 1300 gr. Pada kadar $\mathrm{Hb} 10$ sampai < 11 gr\% karakteristik bayi yang dilahirkan yaitu 2 bayi yang lahir dengan berat badan 2400 gr dan sisanya masing-masing 1 bayi lahir dengan berat badan $2350 \mathrm{~g}, 1300 \mathrm{~g}$, dan 1800g dan Pada kadar $\mathrm{Hb} 8-9,9 \mathrm{gr} \%$ memiliki berat badan 2400 gr dan 2100 gr.

Dari hasil tersebut di atas jelas tidak ada kaitannya kadar $\mathrm{Hb}$ yang rendah menghasilkan berat badan yang kurang. Pada kadar $\mathrm{Hb}$ 8-9,9 gr\% menunjukkan berat badan yang lebih baik dibandingkan dengan kadar $\mathrm{Hb} 10$ sampai < 11 gr $\%$.Dari data ini jelas terlihat bahwa sebagian besar ibu inpartu yang melahirkan bayi berat badan lahir rendah memiliki kadar $\mathrm{Hb}$ yang normal yaitu kadar $\mathrm{Hb} \geq 11$ gr\%. Teori Manuaba (2007) tidak mendukung hasil di atas dengan pernyataannya , bila kadar $\mathrm{Hb}$ ibu hamil kurang dari normal maka dapat mempengaruhi hambatan tumbuh kembang janin dalam rahim. Dengan kata lain bahwa tidak selalu ibu yang melahirkan bayi dengan berat badan lahir rendah selalu memiliki kadar $\mathrm{Hb}$ yang rendah.

Hasil penelitian ini juga diperkuat dengan penelitian dari Setiawan, A dkk (2013) yang menyatakan , rata-rata kadar hemoglobin ibu hamil trimester III adalah $11,16 \mathrm{gr} / \mathrm{dl}$ dan ditemukan ibu hamil yang mengalami anemia sebesar $31,25 \%$. Ratarata berat bayi lahir pada penelitian adalah 3.103 gram dan ditemukan bayi yang mempunyai berat lahir rendah sebesar $3,1 \%$ sehingga kesimpulannya tidak ditemukan adanya hubungan kadar hemoglobin ibu hamil trimester III dengan berat bayi lahir di kota Pariaman, dimana kadar hemoglobin yang di ukur pada ibu hamil trimester III ini juga kurang lebihnya sama dengan kadar hemoglobin ibu inpartu.

Terdapat faktor-faktor yang mempengaruhi terjadinya BBLR, menurut pernyataan Proverawati dan Sulistyorini(2010) bahwa faktor-faktor yang mempengaruhi terjadinya BBLR terdiri dari berbagai macam faktor .Faktor - faktor tersebut bisa berupa dari faktor ibu yaitu berupa penyakit atau komplikasi selama kehamilan seperti Perdarahan antepartum, hipertensi, preeklampsia berat, eklampsia, infeksi selama kehamilan (infeksi kandung kemih dan ginjal, malaria, HIV/AIDS, ibu dengan usia $<20$ tahun atau lebih dari 35 tahun, ibu yang mempunyai riwayat BBLR, keadaan sosial ekonomi yang kurang, ibu perokok / minum alkohol. Faktor lainnya yaitu faktor janin, faktor plasenta dan faktor lingkungan.

Menurut Darmayanti, dkk (2010) menyatakan variabel yang memiliki nilai signifikan terhadap risikoterjadinya BBLR adalah umur kehamilan, paritas,hipertensi dalam kehamilan, riwayat preterm danprenatal care. Variabel yang tidak signifikan adalahusia, jarak kehamilan, riwayat BBLR, anemia danjenis kelamin bayi.

Pernyataan dari Darmayanti, dkk. 2010 nampaknya memiliki sedikit persamaan dari hasil penelitian di RSUD Kabupaten Nganjuk.Dimana lebih dari setengah ibu inpartu yaitu 55\% ada penyulit. Adanya penyulit misalnya seperti hipertensi/preeklasmpsia dan tidak adanya resiko dari usia ibu menyebabkan kelahiran BBLR. Penyulit tersebut ialah (Lampiran 7 halaman 56) yaitu 4 responden dengan PEB, 7 responden dengan PER, 2 responden dengan plasenta previa, 1 responden dengan KPD, 1 responden dengan KPD+PER, 1 responden dengan PER+Plasenta Previa.

\section{Kesimpulan}

Berdasarkan hasil penelitian yang telah dilaksanakan di RSUD Kabupaten Nganjuk, dapat ditarik kesimpulan sebagai berikut:

1. Sebagian besar ibu inpartu yang melahirkan bayi BBLR di RSUD Kabupaten Nganjuk Periode Bulan Maret-April Tahun 2013 memiliki kadar hemoglobin normal. 
2. Mayoritas ibu inpartu yang melahirkan bayi BBLR di RSUD Kabupaten Nganjuk Periode Bulan Maret-April Tahun 2013 melahirkan bayi BBLR dengan klasifikasi bayi BBLR (berat dibawah 2500g)

3. Tidak ada hubungan antara kadar $\mathrm{Hb}$ ibu inpartu terhadap kejadian BBLR di RSUD Kabupaten Nganjuk Periode Bulan Maret-April Tahun 2013

Daftar Pustaka

Adriani, M dan Wirjatmadi, B. 2012 . Peranan Gizi Dalam Siklus Kehidupan. Jakarta Kencana Prenada Media Group.

Alisjahbana, Armida S, dkk. 2010. Laporan Pencapaian Tujuan Pembangunan Milenium Indonesia 2010 BAPPENAS.< http://gizi.depkes.go.id/wpcontent/uploads/2011/10/lappemb-milenium-ind-2010.pdf > akses tanggal 01-02-2014.

Asmadi. 2008. Teknik Prosedural Konsep dan Aplikasi Kebutuhan Dasar Klien. Jakarta : Salemba Medika.

Bakta, I. 2013. Hematologi Klinik Ringkas. Jakarta : EGC.

Darmayanti, dkk. 2010. Pengaruh Kenaikan Berat Badan Rata Rata Per Minggu Pada Kehamilan Trimester Ii Dan III Terhadap RisikoBerat Bayi Lahir Rendah.

$<$ jurnal.ugm.ac.id/bkm/article/view 13481/3008> akses tanggal 5-82014.

Fraser, D. M. dan Cooper M. A. 2011. Buku Ajar Bidan Myles. Jakarta : EGC.

Hidayat, A. A. A. 2007. Metode Penelitian Kebidanan Teknik Analisa Data. Jakarta : Salemba Medika.

J, A.Ren, dkk. 2007. Low First-Trimester Hemoglobin And Low Birth Weight, Preterm Birth And Small For Gestational Age Newborns. $<\mathrm{http}: / /$ ac.els-
dn.com/S0020729207002962/1-

s2.0-S0020729207002962-

main.pdf?tid=67803e72-a159-

11e3-

bcaa00000aacb35d\&acdnat $=1393$

6892910ce4e8fc1ee3acd

45212cdf74a39330b>. akses

tanggal 01-03-2014 jam 23.46

WIB .

Manuaba, dkk. 2007. Pengantar Kuliah Obstetri. Jakarta : EGC

Notoatmodjo, S. 2010. Metodologi Penelitian Kesehatan. Jakarta :PT.RINEKA CIPTA.

Nursalam, 2008. Konsep Dan Penerapan Metodologi Penelitian Ilmu Keperawatan. Jakarta : Salemba Medika. 2009. Konsep Dan Penerapan Metodologi Penelitian Ilmu Keperawatan. Jakarta : Salemba Medika.

, 2011. Konsep Dan Penerapan Metodologi Penelitian Ilmu Keperawatan. Jakarta : Salemba Medika.

Prasasti, S. Hubungan Kadar Hb Ibu Hamil Trimester III Dengan Berat Bayi Lahir Di Wilayah Puskesmas Boyolali II Kecamatan Boyolali Kabupaten Boyolali Tahun2014. <http://www.fkm.undi p.ac.id/data/index.php?action $=4 \& \mathrm{i}$ $\mathrm{dx}=225>$ akses tanggal 15-7-2014

Prawirohardjo, S. 2010. Pelayanan Kesehatan Maternal dan Neonatal. Jakarta : Yayasan Bina Pustaka.

Profil Kesehatan Provinsi Jawa Timur. 2012

http://dinkes.jatimprov.go.id/userfi le/dokumen/1380615402_PROFIL _KESEHATAN_PROVINSI_JAW ATIMUR_2012.pdf akses tanggal 01-01-2014 jam 23.21 WIB.

Proverawati, A. dan Sulistyorini, C. I. 2010. Berat Badan Lahir Rendah.Yogyakarta: Nuha Medika. 
Rahayu, D. E, dkk. 2013. Pedoman Ujan

Akhir Program (UAP) Jurusan Kebidanan Poltekkes Malang.

Rahayu, W. 2005. Hubungan Pencapaian Kadar Hemoglobin Harapan Ibu Hamil Trimester III Dengan Berat Bayi Lahir Di Rumah Sakit Umum Pelayanan Kesejahteraan Umat (PKU) Muhammadiyah Delanngu Kabupaten Klaten. < http://eprints.undip.ac.id/10032/1/2 638.pdf $>$. akses tanggal 01-032014.

Ronnenberg, A.G, dkk. 2004. Preconception Hemoglobin and Ferritin Concentrations Are Associated with Pregnancy Outcome in a Prospective Cohort of Chinese Women. < http://search.proquest.com.ezproxy .ugm.ac.id/docview/197452260/ful ltextPDF/2E8E2C44C7E34E46PQ $/ 1$ ? accountid $=13771$ akses tanggal 01-03-2014 jam 23.46 WIB>.

Rukiyah, Ai Yeyeh dan Lia Yulianti. 2010. Asuhan Kebidanan 4 (Patologi). Jakarta :CV.Trans Info Media.

Sacher, R. A dan McPherson, R.A. 2004. Tinjauan Klinis Hasil Pemeriksaan Laboratorium. Jakarta : EGC

Sari, Reni dan Wulan. 2008. Dangerous Junk Food. Yogyakarta : O2

Saryono dan Mekar D A. 2013. Metodologi Penelitian Kualitatif dan Kuantitatif Dalam Bidang Kesehatan. Yogyakarta : Nuha Medika.

Setiawan, A, dkk. 2013. Hubungan Kadar Hemoglobin Ibu Hamil Trimester III Dengan Berat Bayi Lahir di Kota Pariaman. 〈http://jurnal.fk.unand.ac.id >.akse s tanggal 15-7-2014

Sinsin, I. 2008. Masa Kehamilan Dan Persalinan. Jakarta : PT. Elex Media Komputindo

Sofro, A.S.M. 2011. Darah. Yogyakarta : Pustaka Pelajar
Sugiyono. 2012. Metodologi Penelitian Pendidikan. Bandung : Alfabeta

Sugiyono. 2013. Metodologi Penelitian Pendidikan. Bandung : Alfabeta

Syafrudin dan Hamidah. 2009. Kebidanan Komunitas. Jakarta : EGC 